\title{
Differences in Apoptotic Status in the Bovine Placentome between Spontaneous and Induced Parturition
}

\author{
Hiroki HIRAYAMA ${ }^{1)}$, Koichi USHIZAWA ${ }^{2)}$, Toru TAKAHASHI'), Ken SAWAI'), \\ Satoru MORIYASU1), Soichi KAGEYAMA ${ }^{1}$, Ryotaro MIURA ${ }^{4}$, ,Motozumi MATSUI ${ }^{4)}$, \\ Shigeo FUKUDA ${ }^{1)}$, Akira NAITO ${ }^{1)}$, Takashi FUJII ${ }^{1)}$ and Akira MINAMIHASHI ${ }^{\text {) }}$ \\ 1)Animal Biotechnology Group, Animal Research Center, Hokkaido Research Organization, Hokkaido 081-0038, Japan \\ ${ }^{2)}$ Animal Physiology Research Unit, Division of Animal Science, National Institute of Agrobiological Sciences, \\ Ibaraki 305-0901, Japan \\ 3) Department of Animal Science, Faculty of Agriculture, Iwate University, Iwate 020-8550, Japan \\ ${ }^{4)}$ Department of Clinically Veterinary Sciences, Obihiro University of Agriculture and Veterinary Medicine, \\ Hokkaido 080-8555, Japan
}

\begin{abstract}
We conducted this study to analyze apoptotic changes in the bovine placentome at spontaneous and induced parturition. Cows delivered i) after the administration of dexamethasone followed by prostaglandin $\mathrm{F}_{2 \alpha}$ and estriol, ii) after the administration of prostaglandin $\mathrm{F}_{2 \alpha}$ and estriol or iii) spontaneously. Prepartum changes in plasma progesterone and estradiol$17 \beta$ concentrations were similar between spontaneous and induced parturition. Messenger RNA of BCL2-related protein A1 (BCL2A1), an antiapoptotic gene, was expressed by trophoblast binucleate cells and caruncular epithelial cells. Quantitative RT-PCR showed that the expression of $B C L 2 A 1$ mRNA in cotyledonary and caruncular portions was significantly lower in spontaneous parturition than induced parturition. The expression of BCL2-associated X protein $(B A X) \mathrm{mRNA}$, a proapoptotic gene, was significantly higher in cotyledons at spontaneous parturition than parturition induced without dexamethasone. Caspase-3 (CASP3) mRNA and pre-activated CASP3 protein were predominantly detected in caruncular epithelial cells regardless of how parturition proceeded. Activated CASP3 protein was found in trophoblast uninucleate cells and binucleate cells rather than caruncular epithelial cells. In spontaneous parturition, intense staining of activated CASP3 was detected in caruncular epithelial cells. Spontaneous and dexamethasone-induced parturition increased apoptotic cells in the placentome compared with parturition induced without dexamethasone. The number of binucleate cells was significantly decreased in spontaneous parturition. The present results suggest that although the clinical dose of dexamethasone induces apoptosis in the placentome at term, neither dexamethasone nor prostaglandin $\mathrm{F}_{2 \alpha}$ evoke normal physiological changes in the placentome during delivery such as a change in the balance of apoptosis-related genes and disappearance of binucleate cells.
\end{abstract}

Key words: Apoptosis, Cow, Parturition, Parturition induction, Placenta

(J. Reprod. Dev. 58: 585-591, 2012)

A ppropriate regulation of cell proliferation and regression in the placentome is essential to maintain and complete gestation. In the bovine placentome, the number of apoptotic cells increases as pregnancy progresses and is significantly high at around parturition $[1,2]$. The facilitation of apoptosis seems to reflect placental maturity during the peripartum period. Recent studies have shown that the status of apoptosis in the placentome correlates with the incidence of a retained placenta after parturition [1,3]. In addition, artificial induction of parturition by the administration of a glucocorticoid and/ or prostaglandin $(\mathrm{PG}) \mathrm{F}_{2 \alpha}$ also frequently results in a retained placenta $[4,5]$. These findings suggest that apoptosis in the placentome is required for detachment of the fetal membrane in the early postpartum period, but apoptotic status and its control in the placentome around parturition are not fully understood.

Received: February 17, 2012

Accepted: May 25, 2012

Published online in J-STAGE: June 22, 2012

C 2012 by the Society for Reproduction and Development

Correspondence: H Hirayama (e-mail: hirayama-hiroki@hro.or.jp)
Most cells undergoing apoptosis execute the death program by activating a hierarchy of caspases [6]. In the murine placenta, apoptotic cells and the expression of caspase-3 (CASP3), one of the key executioners of apoptosis, showed temporal and spatial associations $[7,8]$. The BCL2 family members are regulators of caspase-dependent apoptosis and divided into antiapoptotic (BCL2, BCL2A1, BCL2L1, BCL2L2 and MCL1) and proapoptotic (BAX, BAK1 and BOK) proteins. Ushizawa et al. [2] reported that BCL2related protein A1 (BCL2A1) mRNA expression was dominant compared with $B C L 2$ mRNA expression in the bovine placenta and suggested that the balance of $B C L 2 A 1$ and BCL2-associated X protein $(B A X)$ levels would regulate the maintenance and apoptosis of trophoblast binucleate cells.

Cortisol, a principal glucocorticoid in ruminants, is abundantly secreted from the fetal adrenal cortex during the last week of gestation [9]. The induction of estrogen synthesis in the placenta and $\mathrm{PGF}_{2 \alpha}$ synthesis in the maternal endometrium by fetal cortisol are essential for the initiation of spontaneous delivery [10]. Glucocorticoids are known to be proapoptotic and antiapoptotic in different tissues and cell types $[11,12]$, and maternal treatment with a glucocorticoid in 
late pregnancy leads to placental apoptosis in rodents $[13,14]$. In addition, the number of binucleate cells declines near term, and this change could be induced by the administration of glucocorticoids [ 15 , 16]. The proapoptotic effect of glucocorticoids in the placenta appears to occur through a caspase-dependent pathway [17]. However, it is not clear how glucocorticoids used clinically to induce parturition in cows influences placental apoptosis.

In this study, we analyzed changes in the expression of apoptosisrelated genes and apoptotic status in the bovine placentome at parturition by comparing spontaneous and induced parturition, focusing on the effects of dexamethasone on apoptosis in the placentome.

\section{Materials and Methods}

\section{Animals and treatments}

Included in the study were Angus and beef crossbred cows. The cows were kept at the Animal Research Center and fed grass hay and grass silage. Cows delivered 1) after the administration of dexamethasone (20 mg i.m., Kyoritsu Seiyaku, Tokyo, Japan) followed by $\mathrm{PGF}_{2 \alpha}$ (25 mg i.m. dinoprost tromethamine, Pronalgon-F injection, Pfizer Japan, Tokyo, Japan) and estriol (20 mg i.m., Holin, ASKA Pharmaceutical, Tokyo, Japan) 24 h later (DEX group), 2) after the administration of $\mathrm{PGF}_{2 \alpha}$ and estriol without dexamethasone (PG group) or 3) spontaneously (SP group). The induction of parturition was initiated at day $280 \pm 1.1$ or $279 \pm 0.6$ of gestation in the cows used for blood collection in the DEX and PG groups, respectively. The induction of parturition was initiated at day $284 \pm 1.2$ or $284 \pm$ 0.6 of gestation in the cows used for tissue collection in the DEX and PG groups, respectively. The average time (h) from initiation of treatment to calving in the cows used for blood collection in the DEX and PG groups was $50 \pm 5$ or $41 \pm 4$, respectively. The average time (h) from initiation of treatment to calving in the cows used for tissue collection in the DEX and PG groups was $50 \pm 3$ or $43 \pm 5$, respectively. All procedures for animal experiments were carried out in accordance with guidelines and ethics approved by the Animal Experiment Committee of the Animal Research Center.

\section{Sample collection}

Venous blood samples were taken at 36 and 38 weeks of gestation and in the days before parturition. Plasma was harvested by centrifugation and stored at $-20 \mathrm{C}$ until analyzed. Placentomes were collected manually, immediately after vaginal delivery, through the birth canal from cows different from those used for blood collection. Placentomes were fixed in a $10 \%$ formalin neutral buffer solution $(\mathrm{pH}$ 7.4) and embedded in paraffin. Additional placentomes were separated into cotyledons and caruncles and stored at $-80 \mathrm{C}$ prior to the extraction of RNA.

The average period of gestation in the cows used for blood collection was 293 days $(n=5), 282$ days $(n=5)$ and 281 days $(n=5)$ for SP, DEX and PG, respectively. The average period of gestation in cows used for tissue collection was 293 days $(n=4), 287$ days $(n=5)$ and 286 days $(n=4)$ for SP, DEX and PG, respectively.

\section{Hormone assays}

Plasma progesterone (P4) and estradiol $17 \beta$ (E2) concentrations were measured at 36 and 38 weeks of gestation and at the injection of $\mathrm{PGF}_{2 \alpha}$ in the DEX and PG groups, at 2 days before parturition in the SP group and at parturition in all groups. Hormone assays were carried out in duplicate by double-antibody enzyme immunoassay (EIA), as described previously [18]. Plasma P4 and E2 concentrations were assayed after extraction by diethyl ether. The assaying procedures for P4 and E2 were described previously $[19,20]$. The standard curve ranged from 0.05 to $50 \mathrm{ng} / \mathrm{ml}$ for $\mathrm{P} 4$ and from 2 to $2,000 \mathrm{pg} / \mathrm{ml}$ for E2. ED50 values of the assay for P4 and E2 were 2.4 $\mathrm{ng} / \mathrm{ml}$ and $105 \mathrm{pg} / \mathrm{ml}$, respectively. The average inter- and intra-assay coefficients of variation (CV) were, $4.7 \%$ and $6.5 \%$ for $\mathrm{P} 4$ and $6.5 \%$ and $7.6 \%$ for $\mathrm{E} 2$, respectively.

\section{Reverse transcription and real-time PCR}

Total RNA was individually isolated from placental tissues using ISOGEN (Nippon Gene, Toyama, Japan) and reverse transcribed using a QuantiTect Reverse Transcription Kit (QIAGEN GmbH, Hilden, Germany) according to the manufacturer's instructions.

Real-time PCR was performed (run in duplicate) using a QuantiTect SYBR Green PCR Kit (QIAGEN) and a Chromo4 Real-time PCR Detection System (Bio-Rad Laboratories, Hercules, CA, USA) with the following primers: 5'-TTGCAGATACAGCAACCTGGAT-3', forward, and 5'-GGACAGAGGAAGCCACATCTTG-3', reverse, with an annealing temperature of $55 \mathrm{C}$ for BCL2A1 [2], 5'-CGCCCTTTTCTACTTTGCCA-3', forward, and 5'-TCAACTCGGGCACCTTGG-3', reverse, with an annealing temperature of $55 \mathrm{C}$ for $B A X$ [2], 5'-CTTCCACGAAAATACTGGCATG-3', forward, and 5'-TGAATGTTTCCCTGAGGTTTGC-3', reverse, with an annealing temperature of $55 \mathrm{C}$ for $C A S P 3$ [2] and 5'-CCAGAAGACTGTGGATGGCC-3', forward, and 5'-CTGACGCCTGCTTCACCACC-3', reverse, with an annealing temperature of $60 \mathrm{C}$ for $G A P D H$ [21]. The thermal cycling conditions included activation of HotStarTaq DNA polymerase at $95 \mathrm{C}$ for $15 \mathrm{~min}$, followed by 45 cycles of denaturation at $94 \mathrm{C}$ for $15 \mathrm{sec}$, annealing of primers at different temperatures for $30 \mathrm{sec}$ and elongation at 72 $\mathrm{C}$ for $30 \mathrm{sec}$. To quantify the mRNA abundance, standard curves for each gene were generated by serial dilution of a known quantity of purified RT-PCR products. The relative difference in the initial amount of each mRNA species was determined by comparing the $\mathrm{Ct}$ values. We confirmed the melting curve for detecting the SYBR Green-based objective amplicon because SYBR Green detects double-stranded DNA, including primer dimers, contaminating DNA and PCR products from misannealed primers. The expression of each gene is shown relative to that of GAPDH mRNA.

\section{In situ hybridization}

A full-length cDNA of bovine $B C L 2 A 1, B A X$ and $C A S P 3$ was used as the template for producing the probes for hybridization. We prepared digoxigenin (DIG)-labeled antisense- and sense-complementary RNA probes as described previously [22]. In situ hybridization was performed using the automated Ventana Discovery XT System, a Ribo Map Kit and a Blue Map Kit (Roche Diagnostics, Tokyo, Japan). Briefly, $5-\mu \mathrm{m}$ thick sections were hybridized using DIG-labeled probes in RiboHybe hybridization solution (Roche) at $69 \mathrm{C}$ for $B C L 2 A 1$, $67 \mathrm{C}$ for $B A X$ and $65 \mathrm{C}$ for $C A S P 3$ for $6 \mathrm{~h}$. After hybridization, the sections were washed three times in RiboWash (Roche; 65 C, 4 min) and fixed in RiboFix (Roche; 37 C, 20 min). Then hybridization signals 
were detected using a biotin-conjugated monoclonal anti-digoxin antibody (B7405, Sigma-Aldrich, St. Louis, MO, USA).

\section{Immunohistochemistry}

Immunohistochemistry was performed using the Ventana Discovery XT System with a DAB Map kit (Roche). Briefly, 5- $\mu$ m thick sections were incubated with an anti-pre-activated CASP3 (LS-C88629, LifeSpan BioSciences, Seattle, WA, USA) diluted 1:200 in Discovery $\mathrm{Ab}$ diluent (Roche) or anti-activated CASP3 polyclonal antibody (C8487, Sigma-Aldrich) diluted 1:1000 for $60 \mathrm{~min}$ at $37 \mathrm{C}$. The Discovery Ab diluent was used instead of antisera as a negative control. Signals were detected using an anti-rabbit IgG polyclonal antibody biotin conjugate (BA-1000, Vector Laboratories, Burlingame, CA, USA). Sections were counter stained with Mayer's hematoxylin.

\section{TUNEL analysis}

TUNEL was done on 5- $\mu$ m-thick sections with the Ventana Discovery XT System, a DAB Map Kit (Roche) and a ApopTag Peroxidase In Situ Apoptosis Detection Kit (Millipore, Temecula, CA, USA). Briefly, the free 3'OH DNA termini were labeled with DIG-labeled nucleotides and deoxynucleotidyl transferase (TdT) at $37 \mathrm{C}$ for $32 \mathrm{~min}$. Then TUNEL signals were detected using biotinconjugated monoclonal anti-digoxin antibody (B7405, Sigma-Aldrich). Negative control experiments were achieved by omitting the terminal TdT. Sections were counterstained with Mayer's hematoxylin. Three fields $\left(0.594 \mathrm{~mm}^{2} /\right.$ field $)$ of view of each placentome section were recorded under a light microscope with a digital photo system. The area of TUNEL-positive staining was measured by ImageJ (1.42q, http://rsbweb.nih.gov/ij/). The total TUNEL-positive area in three fields was calculated as an apoptotic index and corrected to per $1 \mathrm{~mm}^{2}$.

\section{Trophoblast binucleate cells}

Five-micrometer-thick sections were subjected to hematoxylin-eosin staining. Five fields $\left(0.140 \mathrm{~mm}^{2} /\right.$ field $)$ of view of each placentome section were recorded under a light microscope with a digital photo system. Basal secondary villi or tertiary villi [23] were examined for evaluation of binucleate cells. The total number of binucleate cells in five fields was calculated as a representative value and corrected to per $1 \mathrm{~mm}^{2}$.

\section{Statistical analysis}

All results are presented as the mean \pm SEM. The experimental data were analyzed using the glm function of the R statistical package [24]. Multiple comparison tests were conducted using Bonferroni's or Dunnett's method. A P value $<0.05$ was considered significant.

\section{Results}

\section{Plasma P4 and E2 concentrations}

Plasma P4 concentrations were significantly decreased at 2 days before parturition in the SP group and before the $\mathrm{PGF}_{2 \alpha}$ injection in the PG group compared with the levels at 36 weeks of gestation (Fig. 1A). All groups showed significantly lower plasma P4 concentrations at term. Plasma E2 concentrations were significantly increased at term compared with at 36 weeks of gestation in all groups (Fig. 1B). There was no difference in plasma P4 and E2 concentrations among
A

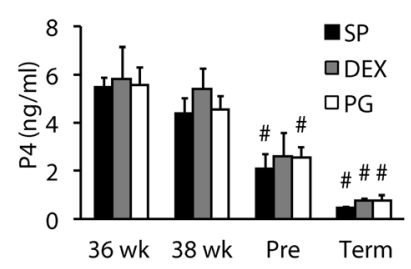

B

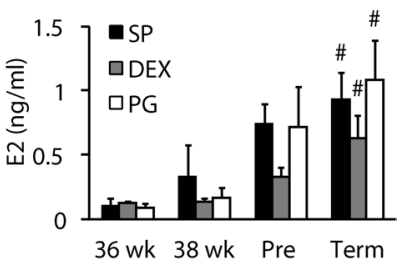

Fig. 1. Hormonal changes in cows during late pregnancy. Plasma progesterone (A) and estradiol $17 \beta$ (B) concentrations were measured in cows that delivered spontaneously (SP) or artificially with the induction of parturition. Parturition was induced with prostaglandin $\mathrm{F}_{2 \alpha}$ and estriol (PG) alone or in combination with dexamethasone (DEX). 36 wk and 38 wk: 36 and 38 weeks of gestation. Pre: at injection of prostaglandin $\mathrm{F}_{2 \alpha}$ in the DEX and PG groups or at 2 days before parturition in the SP group. Term: at parturition. \# Significant difference compared with $36 \mathrm{wk}$ in each group.

the SP, DEX and PG groups.

Messenger RNA levels of BCL2A1, BAX and CASP3 in the placentome at parturition

Placentomal BCL2A1 mRNA abundance was significantly lower in the SP group than in the DEX and PG groups in both the cotyledon (Fig. 2A) and caruncle (Fig. 3A). The SP group had significantly higher levels of $B A X$ mRNA in the cotyledon than the PG group (Fig. 2B). There was no difference in CASP3 mRNA levels among the three groups regardless of the tissue (Figs. $2 \mathrm{C}$ and $3 \mathrm{C}$ ).

\section{Distribution of BCL2A1, BAX and CASP3 $m R N A$ in the placentome}

$B C L 2 A 1$ mRNA expression was found in binucleate cells and caruncular epithelial cells (Fig. 4A and 4B). $B A X$ mRNA was expressed in all trophoblasts including binucleate and uninucleate cells and in caruncular epithelial cells (Fig. 4D and 4E). CASP3 mRNA was localized to caruncular epithelial cells adjacent to basal parts of primary chorionic villi (Fig. $4 \mathrm{G}$ and $4 \mathrm{H}$ ). The distribution of mRNA of all genes was similar among the SP, DEX and PG groups.

\section{Localization of CASP3 protein in the placentome}

Distinct immunostaining of pre-activated CASP3 was found in caruncular epithelial cells in the areas adjacent to basal parts of primary chorionic villi in all groups (Fig. 5A, B and C). Positive immunostaining was detected infrequently in binucleate cells that had infiltrated the caruncular epithelium (Fig. 5B).

Immunostaining for activated CASP3 was found in trophoblast uninucleate and binucleate cells but was rarely found in caruncular epithelial cells in all groups (Fig. 5D and E). Intense staining of the activated CASP3 in caruncular epithelial cells was detected in a part of the placentome following spontaneous parturition (Fig. 5F).

\section{Apoptosis in the placentome}

TUNEL-positive signals were detected in trophoblast uninucleate cells, trophoblast binucleate cells and caruncular epithelial cells in all groups (Fig. 6A and 6B). There were few TUNEL-positive cells 

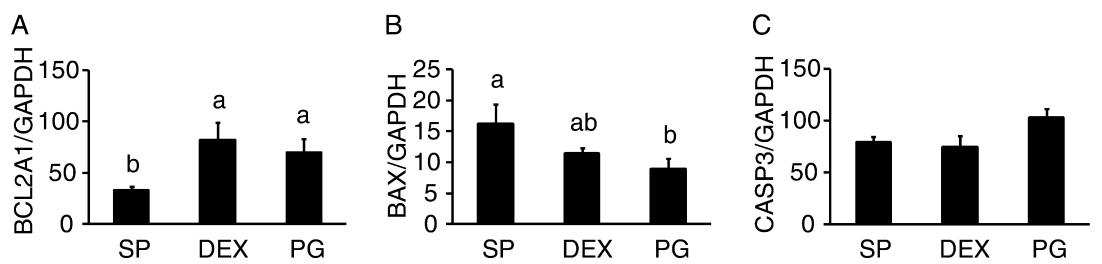

Fig. 2. Expression of apoptosis-related genes in the cotyledon at parturition. Messenger RNA levels of $B C L 2 A 1$ (A), $B A X(\mathrm{~B})$ and $C A S P 3$ (C) were analyzed using real-time RT-PCR. Different letters indicate significant differences $(\mathrm{P}<0.05)$. SP: spontaneous parturition. DEX: parturition induced with dexamethasone, prostaglandin $\mathrm{F}_{2 \alpha}$ and estriol. PG: parturition induced with prostaglandin $\mathrm{F}_{2 \alpha}$ and estriol.
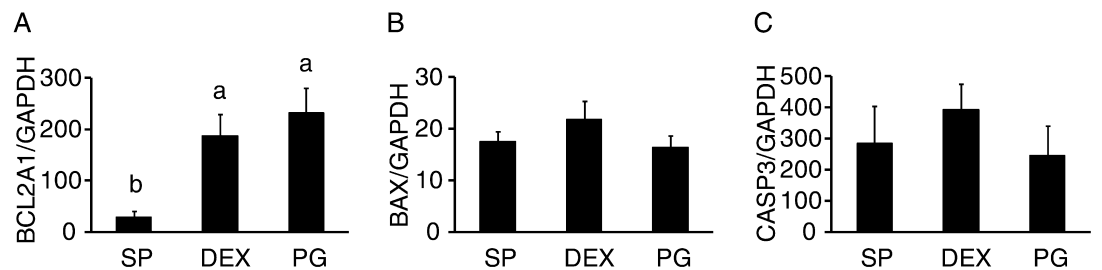

Fig. 3. Expression of apoptosis-related genes in the caruncle at parturition. Messenger RNA levels of $B C L 2 A 1$ (A), $B A X(\mathrm{~B})$ and $C A S P 3$ (C) were analyzed using real-time RT-PCR. Different letters indicate significant differences $(\mathrm{P}<0.05)$. SP: spontaneous parturition. DEX: parturition induced with dexamethasone, prostaglandin $\mathrm{F}_{2 \alpha}$ and estriol. PG: parturition induced with prostaglandin $\mathrm{F}_{2 \alpha}$ and estriol.

in the PG group, and the apoptotic index was significantly lower in the PG group than in the SP and DEX groups (Fig. 6D).

\section{Number of trophoblast binucleate cells}

The number of binucleate cells was significantly lower in the SP group $\left(21 \pm 7 / \mathrm{mm}^{2}\right)$ than in the PG group $\left(149 \pm 17 / \mathrm{mm}^{2}\right)$ or DEX group $\left(128 \pm 12 / \mathrm{mm}^{2}\right)$.

\section{Discussion}

The present study showed that the expression of BCL2A1 and $B A X$ mRNA in the placentome at term varied depending on the procedures of parturition, whereas $C A S P 3$ mRNA levels remained constant. BCL2A1 mRNA was strongly expressed by binucleate cells. Spontaneous parturition resulted in a marked reduction in both $B C L 2 A 1 \mathrm{mRNA}$ expression and the number of binucleate cells in the placentome. The present results suggest that the reduction in BCL2A1 mRNA expression during spontaneous parturition is due to a decrease in the number of binucleate cells as a major source of $B C L 2 A 1 \mathrm{mRNA}$ and is a consequence of the normal progression of parturition. On the other hand, Ushizawa et al. [2] showed that the ratio of $B C L 2 A 1 \mathrm{mRNA}$ to $B A X$ mRNA decreased gradually during late pregnancy. This finding indicates that the stimulation of apoptosis plays a critical role in placental maturation during late pregnancy. In the present study, it was not known if treatments to induce parturition affected mRNA expression because placentomal samples were not taken sequentially during the prepartum period. However, the induction of parturition using $\mathrm{PGF}_{2 \alpha}$ either alone or with dexamethasone resulted in significantly higher $B C L 2 A 1$ mRNA expression in the placentome compared with spontaneous parturition. Thus, it seemed that these procedures to induce parturition did not cause a prepartum decrease of $B C L 2 A 1$ mRNA expression as in spontaneous parturition. If the expression of $B C L 2 A 1$ and $B A X$ mRNA changed in advance of the disappearance of binucleate cells in spontaneous parturition, the parturition induction methods used here could not mimic the placental maturation in terms of the changes in the expression of apoptosis-related genes.

Dexamethasone treatment in the DEX group did not affect either $B C L 2 A 1$ mRNA expression or the number of binucleate cells compared with the PG group. Glucocorticoid treatment caused repression of $B C L 2 A 1$ mRNA expression in lymphoma and thymocyte cell lines $[25,26]$. In addition, direct fetal cortisol infusion and maternal betamethasone administration in sheep have been shown to reduce the number of binucleate cells $[15,16]$. Therefore, the dose of dexamethasone used clinically to induce parturition in cows might be insufficient to cause physiological change and a reduction in numbers of binucleate cells. There has been considerable research on the type and dose of glucocorticoids aimed at reducing the incidence of retained placenta in induced parturition [27, 28]. Long-acting glucocorticoids appeared to result in fewer retained placentas [29]. To reduce the incidence of retained placenta following induced parturition, it is important to clarify the relationship between dose and types of glucocorticoids and placental apoptosis.

It has been suggested that cows in which parturition is induced may deliver without sufficient blood estrogen concentrations to result in normal placental delivery [30]. Exogenous estrogens were used in 

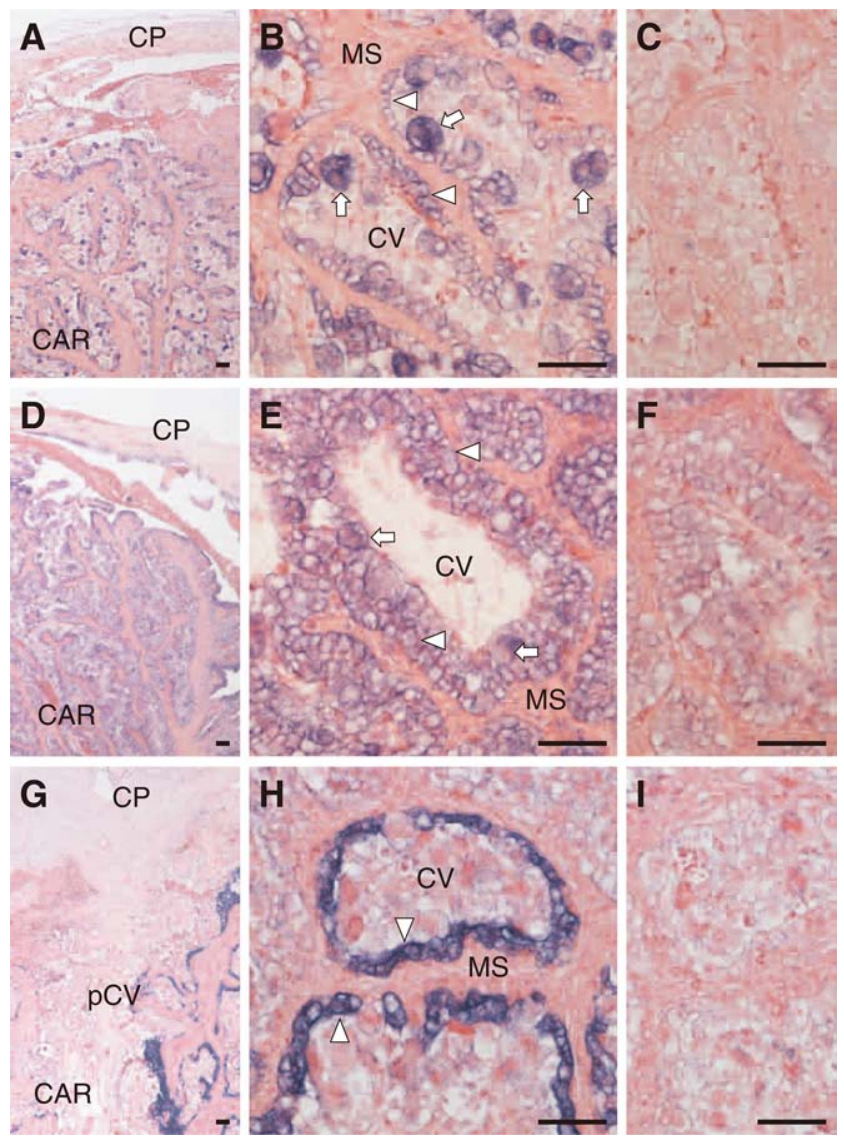

Fig. 4. Localization of $B C L 2 A 1, B A X$ and $C A S P 3$ mRNA in the placentome at parturition. Representative results in the DEX group are shown. BCL2A1 (A and $\mathrm{B}), B A X(\mathrm{D}$ and $\mathrm{E})$ and $C A S P 3$ $(\mathrm{G}$ and $\mathrm{H})$ mRNA were detected by in situ hybridization. Negative controls were hybridized with sense cRNA probes (C, F and I). Arrows and arrowheads indicate binucleate cells and caruncular epithelial cells with positive staining by anti-sense cRNA probes, respectively. CP: chorionic plate. pCV: primary chorionic villus. CAR: caruncle. MS: maternal septum. CV: chorionic villus. Scale $\mathrm{bar}=50 \mu \mathrm{m}$.

various induction regimes to mimic the normal prepartum rise in the blood concentration of estrogens $[31,32]$. In this study, the effects of estriol on the expression of apoptosis-related genes or reduction in the number of binucleate cells could not be evaluated because an induction regime without estriol was not attempted. However, estriol could not induce placental maturation in terms of apoptosis to the same degree as spontaneous parturition. In order to evaluate the effects of estrogens on placental maturity, estradiol that has higher estrogenic activity than estriol should be examined in the future.

Although the CASP3 mRNA and pre-activated CASP3 protein were predominantly detected in caruncular epithelial cells adjacent to the basal parts of primary chorionic villi regardless of whether cows delivered spontaneously or were induced, the activated CASP3 protein was mainly found in trophoblast uninucleate and binucleate cells. These results may imply that the apoptosis in caruncular epithelial cells lags behind that in trophoblast cells and first occurs close to the cotyledon. Boos et al. [1] described that placental maturation, that is a reduction in numbers of maternal epithelial cells by apoptosis, is a time-consuming process than involves an induction of labor and expulsion of the fetus. The presence of CASP 3 mRNA and pre-activated CASP3 protein in caruncular epithelial cells supports that placental maturation is ongoing at parturition. Furthermore, the observation of activated CASP3 protein in caruncular epithelial cells in the SP group suggests that the placentome from full-term spontaneous parturition is more mature than that from induced parturition in the last week of the estimated gestation length. In spontaneous parturition, the decrease in the expression of $B C L 2 A 1$ mRNA, which is an antiapototic factor in the apoptosis cascade, might facilitate cleavage and activation of downstream effector caspases such as CASP3 protein.

Apoptotic signals were detected by the TUNEL assay in caruncular epithelial cells and trophoblast cells including binucleate cells. The expression of $B C L 2 A 1, B A X$ and $C A S P 3$ mRNA in caruncular epithelial cells and binucleate cells suggests that BCL2A1 acts as a regulator of caspase-dependent apoptosis. However, trophoblast uninucleate cells did not express $B C L 2 A 1 \mathrm{mRNA}$. This result implies that other antiapoptotic genes act as a regulator in the cell. The SP and DEX groups showed significantly high numbers of apoptotic cells compared with the PG group. The average apoptotic index in the SP group was high because of a cow with a very large number of apoptotic cells, and there was no significant difference between the SP and DEX groups. In contrast, very few apoptotic cells were found in the placentome when parturition was induced without dexamethasone. Therefore, it was suggested that dexamethasone acted as a proapoptotic factor in the placentome at parturition. Dexamethasone seems to affect caruncular epithelial cells and binucleate cells that show strong immunostaining for glucocorticoid receptor [33]. Because the number of binucleate cells did not change in the present study, the clinically used dose of dexamethasone might induce apoptosis in caruncular epithelial cells. We induced parturition in the last week of gestation. The induction of parturition caused luteolysis and estrogen synthesis and resulted in successful expulsion of the fetus. Therefore, the procedures used clinically to induce parturition seemed to give rise to the physiological changes needed for parturition. However, placental maturity in terms of apoptosis at parturition was suggested to be insufficient.

Collagen links the interface between cotyledons and caruncles, and the breakdown of this collagen is likely a key factor in placental separation. In fact, it was reported that administration of collagenases via the umbilical cord induced the detachment of fetal membranes [34]. Matrix metalloproteinases (MMPs) and tissue inhibitors of MMPs (TIMPs) play an important role in the degradation of extracellular matrix (ECM) such as collagens. The interaction between the remodeling of ECM and apoptosis remains to be clarified. However, it is known that binucleate cells express TIMP-2, which is an inhibitor of MMPs [35]. The expression of TIMP-2 mRNA in the cotyledon decreased at parturition and remained at a low level until $12 \mathrm{~h}$ after parturition [36]. These findings imply that MMP activity in term placentomes might be upregulated by disappearance of binucleate cells and downregulation of TIMP-2 activity. Changes in cellular composition by apoptosis may be involved in the process of detachment of fetal membranes.

In conclusion, despite dexamethasone inducing apoptosis in the 


\section{Pre-activated CASP3}

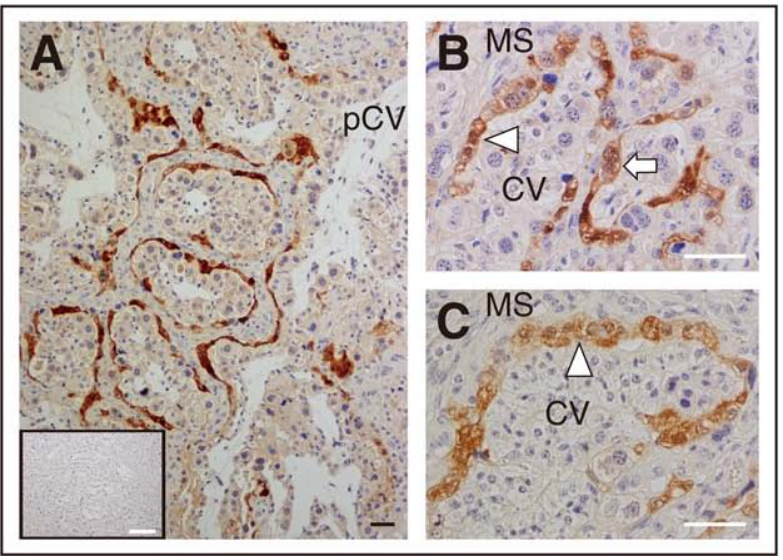

Activated CASP3

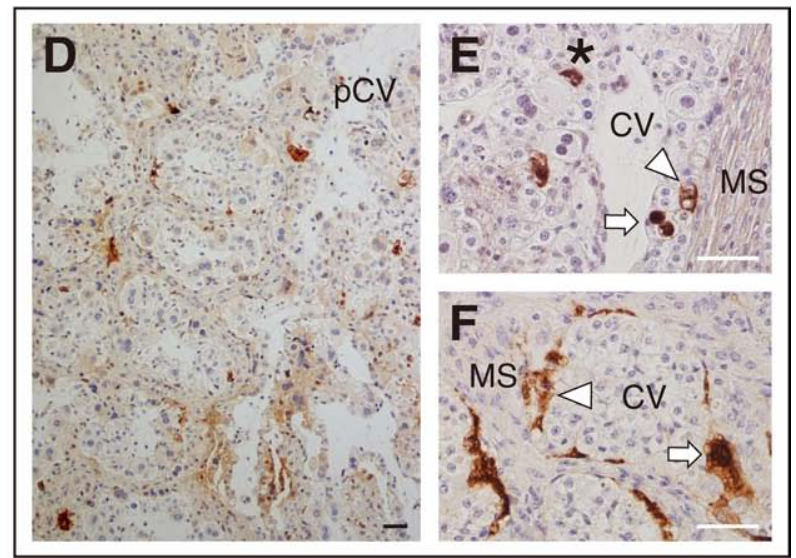

Fig. 5. Localization of CASP3 protein in the bovine placentome at parturition. A and B: detection of the pre-activated CASP3 protein in the DEX group. The insert in panel A shows the negative control. C: detection of the pre-activated CASP3 protein in the SP group. D and E: detection of the activated CASP3 protein in the DEX group. F: detection of the activated CASP3 protein in the SP group. Arrows, arrowheads and the asterisk indicate trophoblast binucleate cells, caruncular epithelial cells and trophoblast uninucleate cells with positive staining, respectively. pCV: primary chorionic villus. MS: maternal septum. CV: chorionic villus. Black bar $=100 \mu \mathrm{m}$. White bar $=50 \mu \mathrm{m}$.
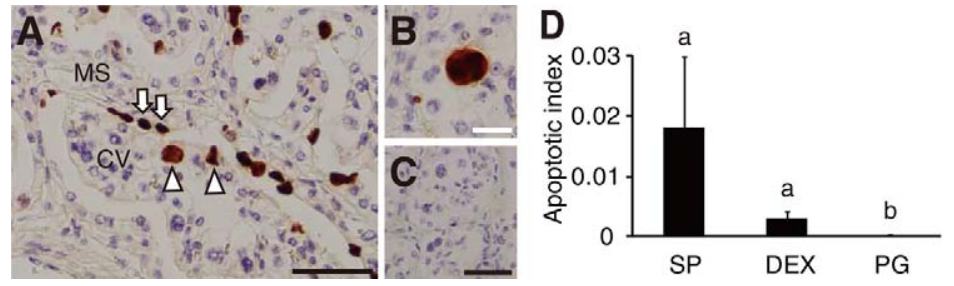

Fig. 6. Apoptosis in the placentome at parturition. A: TUNELpositive signals in trophoblast uninucleate cells (arrowheads) and caruncular epithelial cells (arrows) at parturition induced with dexamethasone. B: a TUNEL-positive binucleate cell at parturition induced with dexamethasone. C: the negative control. D: the apoptotic index calculated from areas with TUNEL signals. MS: maternal septum. CV: chorionic villus. Black bar $=50 \mu \mathrm{m}$. White bar $=20 \mu \mathrm{m}$. Different letters for each group indicate a significant difference $(\mathrm{P}<0.05)$. SP: spontaneous parturition. DEX: parturition induced with dexamethasone, prostaglandin $\mathrm{F}_{2 \alpha}$ and estriol. PG: parturition induced with prostaglandin $\mathrm{F}_{2 \alpha}$ and estriol. placentome at parturition, no change in the expression of apoptosisrelated genes or reduction in the number of binucleate cells was caused by the artificial induction of parturition. Contrary to the proapoptotic action of glucocorticoid in the placenta, no reduction in the incidence of retained placenta on administration of dexamethasone has been reported [4]. This study suggested that clinical treatment for induction of parturition using $\mathrm{PGF}_{2 \alpha}$ either alone or with dexamethasone does not evoke adequate physiological changes in the placentome and that insufficiency of placental maturity might cause the placenta to be retained when parturition is induced. In the future, techniques for inducing parturition need to be improved in terms of placental maturity based on placental apoptosis.

\section{Acknowledgments}

This study was supported by MEXT KAKENHI Grant Number 21780255 and 23013002.

\section{References}

1. Boos A, Janssen V, Mulling C. Proliferation and apoptosis in bovine placentomes during pregnancy and around induced and spontaneous parturition as well as in cows retaining the fetal membranes. Reproduction 2003; 126: 469-480. [Medline] [CrossRef]

2. Ushizawa K, Takahashi T, Kaneyama K, Hosoe M, Hashizume K. Cloning of the bovine antiapoptotic regulator, $\mathrm{BCL} 2$-related protein $\mathrm{A} 1$, and its expression in trophoblastic binucleate cells of bovine placenta. Biol Reprod 2006; 74: 344-351. [Medline] [CrossRef]

3. Kamemori Y, Wakamiya K, Nishimura R, Hosaka Y, Ohtani S, Okuda K. Expressions of apoptosis-regulating factors in bovine retained placenta. Placenta 2011; 32: 20-26. [Medline] [CrossRef]

4. Lewing FJ, Proulx J, Mapletoft RJ. Induction of parturition in the cow using cloprostenol and dexamethasone in combination. Can Vet $J 1985 ; 26$ : 317-322. [Medline]

5. Garcia A, Barth AD, Mapletoft RJ. The effects of treatment with cloprostenol or dinoprost within one hour of induced parturition on the incidence of retained placenta in cattle. Can Vet J 1992; 33: 175-183. [Medline]

6. Cohen GM. Caspases: the executioners of apoptosis. Biochem J 1997; 326: 1-16. [Medline]

7. Burdon C, Mann C, Cindrova-Davies T, Ferguson-Smith AC, Burton GJ. Oxidative stress and the induction of cyclooxygenase enzymes and apoptosis in the murine placenta. Placenta 2007; 28: 724-733. [Medline] [CrossRef]

8. Mu J, Kanzaki T, Si X, Tomimatsu T, Fukuda H, Fujii E, Hosono T, Murata Y, Sugimoto Y, Ichikawa A. Apoptosis and related proteins during parturition in prostaglandin F receptor-deficient mice. Biochem Biophys Res Commun 2002; 292: 675-681. [Medline] [CrossRef]

9. Comline RS, Hall LW, Lavelle RB, Nathanielsz PW, Silver M. Parturition in the cow: endocrine changes in animals with chronically implanted catheters in the foetal and maternal circulations. J Endocrinol 1974; 63: 451-472. [Medline] [CrossRef]

10. Whittle WL, Patel FA, Alfaidy N, Holloway AC, Fraser M, Gyomorey S, Lye SJ, Gibb W, Challis JR. Glucocorticoid regulation of human and ovine parturition: the relationship between fetal hypothalamic-pituitary-adrenal axis activation and intrauterine 
prostaglandin production. Biol Reprod 2001; 64: 1019-1032. [Medline] [CrossRef]

11. Almawi WY, Melemedjian OK, Jaoude MM. On the link between Bcl-2 family proteins and glucocorticoid-induced apoptosis. J Leukoc Biol 2004; 76: 7-14. [Medline] [CrossRef]

12. Herr I, Gassler N, Friess H, Buchler MW. Regulation of differential pro- and anti-apoptotic signaling by glucocorticoids. Apoptosis 2007; 12: 271-291. [Medline] [CrossRef]

13. Waddell BJ, Hisheh S, Dharmarajan AM, Burton PJ. Apoptosis in rat placenta is zone-dependent and stimulated by glucocorticoids. Biol Reprod 2000; 63: 1913-1917. [Medline] [CrossRef]

14. Baisden B, Sonne S, Joshi RM, Ganapathy V, Shekhawat PS. Antenatal dexamethasone treatment leads to changes in gene expression in a murine late placenta. Placenta 2007; 28 : 1082-1090. [Medline] [CrossRef]

15. Ward JW, Wooding FB, Fowden AL. The effects of cortisol on the binucleate cell population in the ovine placenta during late gestation. Placenta 2002; 23: 451-458. [Medline] [CrossRef]

16. Braun T, Li S, Moss TJ, Newnham JP, Challis JR, Gluckman PD, Sloboda DM. Maternal betamethasone administration reduces binucleate cell number and placental lactogen in sheep. $J$ Endocrinol 2007; 194: 337-347. [Medline] [CrossRef]

17. Chan J, Rabbitt EH, Innes BA, Bulmer JN, Stewart PM, Kilby MD, Hewison M. Glucocorticoid-induced apoptosis in human decidua: a novel role for 11 beta-hydroxysteroid dehydrogenase in late gestation. J Endocrinol 2007; 195: 7-15. [Medline] [CrossRef]

18. Miyamoto A, Okuda K, Schweigert FJ, Schams D. Effects of basic fibroblast growth factor, transforming growth factor-beta and nerve growth factor on the secretory function of the bovine corpus luteum in vitro. $J$ Endocrinol 1992; 135: 103-114. [Medline] [CrossRef]

19. Acosta TJ, Miyamoto A, Ozawa T, Wijayagunawardane MP, Sato K. Local release of steroid hormones, prostaglandin E2, and endothelin-1 from bovine mature follicles in vitro: effects of luteinizing hormone, endothelin-1, and cytokines. Biol Reprod 1998; 59: 437-443. [Medline] [CrossRef]

20. Acosta TJ, Yoshizawa N, Ohtani M, Miyamoto A. Local changes in blood flow within the early and midcycle corpus luteum after prostaglandin $\mathrm{F}$ (2 alpha) injection in the cow. Biol Reprod 2002; 66: 651-658. [Medline] [CrossRef]

21. Sawai K, Kageyama S, Moriyasu S, Hirayama H, Minamihashi A, Onoe S. Changes in the mRNA transcripts of insulin-like growth factor ligand, receptors and binding proteins in bovine blastocysts and elongated embryos derived from somatic cell nuclear transfer. $J$ Reprod Dev 2007; 53: 77-86. [Medline] [CrossRef]

22. Kizaki K, Yamada O, Nakano H, Takahashi T, Yamauchi N, Imai K, Hashizume K. Cloning and localization of heparanase in bovine placenta. Placenta 2003; 24: 424-430. [Medline] [CrossRef]

23. Schuler G, Ozalp GR, Hoffmann B, Harada N, Browne P, Conley AJ. Reciprocal expression of 17alpha-hydroxylase-C17,20-lyase and aromatase cytochrome P450 during bovine trophoblast differentiation: a two-cell system drives placental oestrogen synthesis.
Reproduction 2006; 131: 669-679. [Medline] [CrossRef]

24. R Development Core Team R: A language and environment for statistical computing. $R$ Foundation for Statistical Computing, 2010.

25. Planey SL, Derfoul A, Steplewski A, Robertson NM, Litwack G. Inhibition of glucocorticoid-induced apoptosis in 697 pre-B lymphocytes by the mineralocorticoid receptor N-terminal domain. J Biol Chem 2002; 277: 42188-42196. [Medline] [CrossRef]

26. Bianchini R, Nocentini G, Krausz LT, Fettucciari K, Coaccioli S, Ronchetti S, Riccardi C. Modulation of pro- and antiapoptotic molecules in double-positive (CD4+CD8+) thymocytes following dexamethasone treatment. J Pharmacol Exp Ther 2006; 319 887-897. [Medline] [CrossRef]

27. Wagner WC, Willham RL, Evans LE. Controlled parturition in cattle. J Anim Sci 1974; 38: 485-489. [Medline]

28. Welch RAS, Crawford JE, Duganzich DM. Induced parturition with corticosteroids: a comparison of four treatments. N Z Vet J 1977; 25: 111-114. [Medline] [CrossRef]

29. Bo GA, Fernandez M, Barth AD, Mapletoft RJ. Reduced incidence of retained placenta with induction of parturition in the cow. Theriogenology 1992; 38: 45-61. [Medline] [CrossRef]

30. Beardsley GL, Muller LD, Garverick HA, Ludens FC, Tucker WL. Initiation of parturition in dairy cows with dexamethasone. II. Response to dexamethasone in combination with estradiol benzoate. J Dairy Sci 1976; 59: 241-247. [Medline] [CrossRef]

31. Barth AD, Adams WM, Manns JC, Rawlings NC. Induction of parturition in beef cattle using estrogens in conjunction with dexamethasone. Can Vet J 1978; 19: 175-180. [Medline]

32. Davis DL, Kesler DJ, Jenkins AL, Garverick HA, Massey JW, Bierschwal CJ, Day BN. Induction of parturition in cattle with long and short acting corticoids and estradiol benzoate. J Anim Sci 1979; 49: 560-566. [Medline]

33. Boos A, Kohtes J, Stelljes A, Zerbe H, Thole HH. Immunohistochemical assessment of progesterone, oestrogen and glucocorticoid receptors in bovine placentomes during pregnancy, induced parturition, and after birth with or without retention of fetal membranes. $J$ Reprod Fertil 2000; 120: 351-360. [Medline] [CrossRef]

34. Eiler H, Hopkins FM. Successful treatment of retained placenta with umbilical cord injections of collagenase in cows. J Am Vet Med Assoc 1993; 203: 436-443. [Medline]

35. Walter I, Boos A. Matrix metalloproteinases (MMP-2 and MMP-9) and tissue inhibitor-2 of matrix metalloproteinases (TIMP-2) in the placenta and interplacental uterine wall in normal cows and in cattle with retention of fetal membranes. Placenta 2001; 22: 473-483. [Medline] [CrossRef]

36. Takagi M, Yamamoto D, Ohtani M, Miyamoto A. Quantitative analysis of messenger RNA expression of matrix metalloproteinases (MMP-2 and MMP-9), tissue inhibitor-2 of matrix metalloproteinases (TIMP-2), and steroidogenic enzymes in bovine placentomes during gestation and postpartum. Mol Reprod Dev 2007; 74: 801-807. [Medline] [CrossRef] 